\section{Geology of North Africa}

\author{
by E. Edward Tawadros
}

CRC Press/Balkema, London, 2012

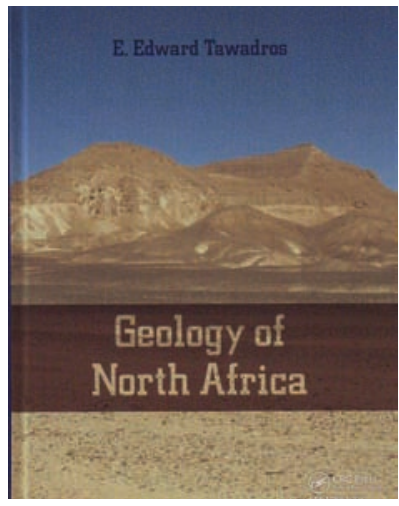

When we hear of North Africa we think of the pyramids, lively Arabic souks (or markets), Roman ruins, and of course the world's largest hot desert-the Sahara. It is here that we find fascinating landscapes with perfect outcrops. Fieldwork gives us a good excuse to get away from civilization for a time and live and work to the rhythm of Nature. Those who have previously worked here will always try to come back. North Africa offers geology for every possible taste, from Precambrian crystalline basement to current Red Sea corals. The region also hosts abundant economic resources, from groundwater over oil and gas to phosphorites and mineral ores. Numerous wells have penetrated North Africa allowing us to reconstruct the deep subsurface in great detail. After the turbulences of the recent Jasmine revolution, life and activities in North Africa are now (we may hope) gradually returning to normal.

The North African deserts of Morocco, Algeria, Tunisia, Libya and Egypt have been geologically explored since the nineteenth century. A massive amount of literature has accumulated and the pile of papers is still increasing by the day. It is hard to keep an overview of what is available. Nevertheless it is vital for every project to have the right papers readily available and locate them quickly. Despite the Sahara's vastness there is hardly any geological subject left that has remained entirely unstudied. Checking the literature is saving lots of time and money, avoids unnecessary duplication of work.

Edward Tawadros has, then, done a great favour to all geologists working in or on the region by compiling a new reference volume on the geology of North Africa. It weighs
$2 \mathrm{~kg}$, has 931 pages and cites some 2,500 references. An index helps the reader to locate 'not-so-well-known' items such as the Tizi ben Tizuit Formation or the Chameau Mort Sandstone. The book is thus a real treasure trove for geologists working in North African projects. Essentially it is a revised and significantly expanded edition of the author's Geology of Egypt and Libya published some ten years ago. Edward Tawadros knows the region well. He spent his early university years in Cairo before obtaining his MSc and $\mathrm{PhD}$ degrees in Scotland and Canada. Subsequently he worked in North Africa as staff geologist and geological consultant for various companies. And he certainly lost his heart to the region, otherwise he would not have spent all these hours writing the book and drafting the many figures.

The work is subdivided into six parts. In Part 1, the author describes the history of geological research and petroleum exploration. This is where the North African all-time rock stars appear: Ardito Desio in Libya, Rushdi Said in Egypt, and Eberhard Klitzsch who has worked in both countries. Those who are already familiar with North Africa will particularly enjoy these historical chapters. Other readers, however, would probably prefer an integrated overview of the geology as well as a description of the present-day petroleum and mining activities.

Part 2 deals with the tectonics of North Africa. In an encyclopedic way Tawadros lists numerous details that may become useful for the reader if he or she has a project in one of the regions mentioned in the chapters.

In Part 3 Tawadros reports on the Precambrian basement. This makes sense, as it forms the base for the subsequent Phanerozoic sedimentation. The chapter provides the reader with a comprehensive account of the basic facts and literature of the crystalline North African substrate, even though I would disagree with the author on the usage of the term 'Pan-African-Shield'. The summary at the end of Part 3 might in fact have been a good introduction to the subject.

Part 4, with over four hundred pages, forms the core of the book and deals with the Phanerozoic stratigraphy of North Africa. There is hardly any North African formation that is not described here in detail. For many wells, the latitude and longitude coordinates are given, which is a valuable feature, especially for readers who do not have ready access to large commercial well data-bases. Part 4 contains an impressive amount of information, ranging from fossil lists through lithological data to petroleum well results. Photographs and simple line sketches illustrate some of the matters discussed. While the drawings are surely fit for purpose, they sometimes have a technical yet somewhat simplistic appearance. Nevertheless, it is helpful that they all are drafted in a similar style, given that their source figures originate from a great number of different publications. The text could have benefited from more lower-hierarchy headings. Occasionally there are up to nine pages of technically written text without any further subdivision. In places, the author has included additional information on the history of geological and petroleum exploration. This information might perhaps have been better integrated into the dedicated history chapters at the beginning. Also the system of chapter and subchapter numbering is not always easy to follow. Section 4.9 ('Moroccan marginal basins'), for example, is empty and only seems to serve as the umbrella term for the basins described in sections 4.10 to 4.13 .

In Part 5 the reader will find detailed information on North African Petroleum systems. Again this will be mostly of interest to North Africa specialists due to the high level of detail and it is well worth digging into these chapters. But after having worked through 635 pages of North African geological history, it was a bit of a surprise to find the final part of the book, Part 6, entitled 'Phanerozoic geological history'. However, it turned out to be a most useful set of chapters where, on the basis of the many small data mosaic pieces mentioned in the book, a comprehensive description of an integrated tectonic and depositional development is attempted. This is certainly the part that is most fun to read. The palaeogeography helps to make sense out of the many lithostratigraphic formation descriptions. However, the petroleum geology section might have been better placed after this integrating part, as it will help to predict the lateral and vertical variation of the petroleum play parameters.

Such comments notwithstanding, the book is an impressive and extremely useful piece of work. There is no regional compilation on this detailed level available anywhere else. Like its predecessor, Geology of Egypt and Libya, the new and expanded volume, Geology of North Africa, will surely become the standard reference for the geology of this important region.

\section{Sebastian Lüning, Bremen,} www.northafrica.de 